\title{
Landsbyskolerapporter fra Skovhuse og Bevtoft 1938 og 1940
}

\section{Ved Lars N. Henningsen}

Fra 1930 'erne fik mange seminarister i studietiden to ugers praktik i en landsbyskole. De skrev rapporter om deres erfaringer, og disse rapporter giver et meget anskueligt billede af de små landsbyskolers indretning. Her gengives to eksempler på disse beretninger fra en i dag helt glemt skoleform.

Frem til 1950'erne var det danske skolelandskab præget af mange små landsbyskoler. Det var en-, to- og treklassede skoler med arbejdsformer og arbejdsbetingelser helt forskellige fra de mangeklassede byskoler. For unge lærere, som kun havde praktiske erfaringer fra seminariernes store øvelsesskoler, kunne det være svært at overtage undervisningen på landet.

Statens Seminarieskole i Haderslev prøvede fra 1920'erne at bøde på disse mangler. I efteråret 1925 tog eleverne i 3. klasse (ældste klasse) på heldagsbesøg i den treklassede skole i Hoptrup. De to følgende år blev forsøget gentaget ved besøg i andre landsbyskoler. I sommeren 1928 foreslog seminarieskolen at udvide besøgene til at omfatte 14 dage, med en eller to seminarieelever ved hver skole.'

Initiativet vakte opsigt, og i seminariebekendtgørelsen af 4. maj 1931 fik det almen gyldighed. Bekendtgørelsens $\S 33$ muliggjorde, at (seminarie)eleverne i 3die og 4die Kl. under betryggende Vejledning faar Adgang til at overvære og deltage i Undervisningen i andre Børneskoler i Seminariets Nærhed saavel ved kortere Besøg som under et uafbrudt Ophold paa højst 3 Uger «. Efter opholdet skulle eleverne afgive rapport om de pågældende skolers indretning, undervisningsmetoder 0 . lign. Lignende bestemmelser blev optaget $\mathrm{i}$ bekendtgørelsen af 29. februar 1940. Elevernes rapporter fra landsbyskolerne kunne, såfremt de blev antaget af censorerne, få indflydelse på eksamenskarakteren $\mathrm{i}$ praktisk skolegerning.

I 1930'erne kom seminaristerne fra både Haderslev og Tønder seminarier på landsbyskoleophold. I Haderslev foregik det på den måde, at eleverne onskede sig en eller anden skole $i$ landsdelen. Seminariet formidlede forbindelsen, og den vordende lærer betalte $40 \mathrm{kr}$. selv for logi og kost $\mathrm{i}$ de to uger. Seminariet betalte den anden halvdel. I første uge skulle seminaristen være 
iagttagende, og den anden uge selv overtage undervisningen helt på egen hånd. $^{2}$

Enkelte lærere har senere fortalt om deres landsbyskoleophold. Nina Langkilde, dim. Haderslev 1941, har her i Sønderjyske Årbøger 1988 berettet fra sin tid i Knud skole i juni 1940. Chr. Stenz har i sine erindringer (1982) ${ }^{3}$ givet glimt fra sin tid i Ravsted i 1934.

Rapporterne fra de to ugers ophold blev efter dimission leveret tilbage til seminarieeleverne. De findes derfor ikke i seminariernes arkiver, men skjuler sig i lærernes private gemmer. Det er imidlertid værd at gøre opmærksom på »landsbyskolerapporterne" som skolehistorisk kilde. De giver et detaljeret billede af livet i de små skoler, af undervisningsformen, hvor flere hold blev undervist samtidig, af skolernes udstyr. I enkelte rapporter er der også korte sideblik til det »omgivende samfund «.

I det følgende fremdrages to eksempler på genren. Begge er skrevet af lærere født på Rødding-egnen og med en lang efterfølgende lærergerning i Sydslesvig. Først gengives lærer Johannes Finks beretning 1938 fra Skovhuse skole på Rønhave-halvøen i Ulkebøl sogn. Fink var født 1915 i Brændstrup ved Rødding. I 1939 tog han lærereksamen i Tønder. Efter en tid i Tandslet virkede han som lærer ved den danske privatskole i Valsbøl 1945-59. Derefter fulgte embeder i Bjerndrup ved Tinglev og i Vester Sottrup indtil 1977. Fink døde i Kollund i $1988^{4}$

Beretningen fra Bevtoft 1940 skyldes Anna Schrøder. Hun var født 1919 i Rødding og virkede fra 1946 til 1970 som leder af den danske skole i Aventoft syd for Tønder. Efter pensioneringen boede Anna Schrøder fra 1986 i Tønder, hvor hun døde $1990 .^{5}$

\section{Skovhuse skole ${ }^{6}$}

\section{af Johannes Fink}

Landsbyen Skovhuse ligger ca. $7 \mathrm{~km}$ nord for Sønderborg ude på Karhalvøen. Landsbyen har en ret ejendommelig historie. På halvøen ligger godset Rønhave. Dette ejedes gennem århundreder af adelsslægten Holck, som omkring år 1600 afhændede det til hertug Hans, der efter tidens skik ville have sine jorder samlede i store sammenhængende stykker. Nord for Rønhave lå dengang nogle fæstegårde, som kaldtes Skovhuse. Disse gårde rev hertugen ned og lagde deres jorder ind under Rønhave. Navnet Skovhuse forsvandt. Rønhave ejede hele den nordlige del af Kær-halvøen. Efter en lang tidsperiode med flere ejerskifter kom Rønhave omsider ind under den tyske stat som statsdomæne, og efter 1920 blev godset dansk statsejendom. I 1926 blev der 


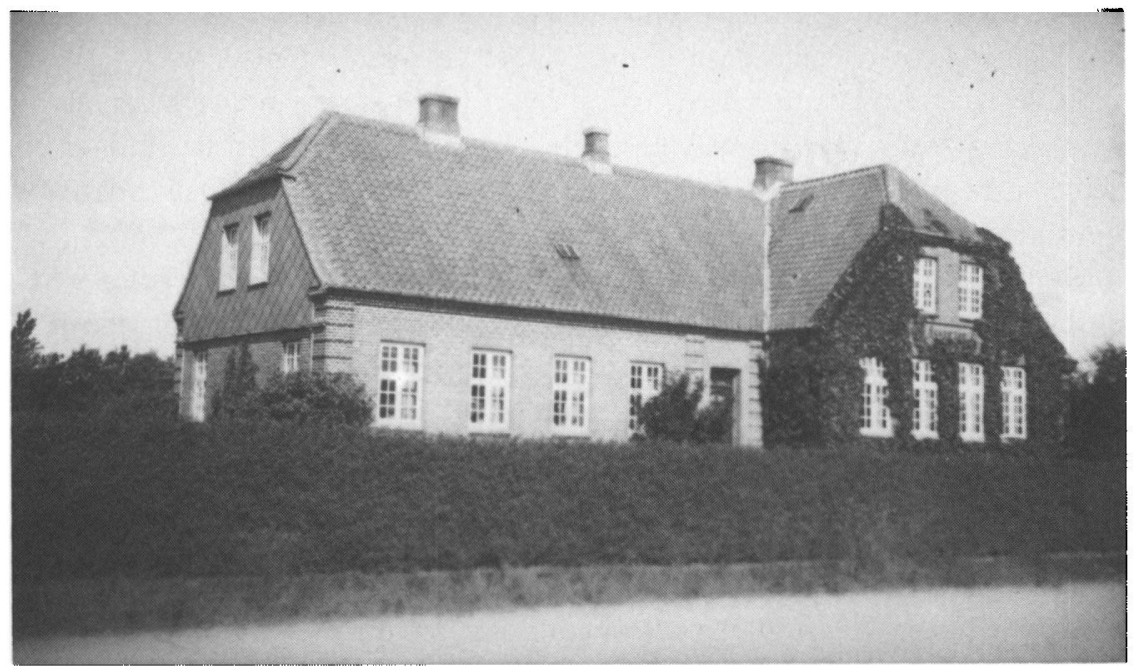

Skovhuse skole. De to klassevarelser lå til hojre, larerens bolig i langen til venstre. Skolerne i Skovhuse og Bevtoft (side 254) lignede hinanden meget på trods af, at den ene var bygget for Genforeningen i 1912, den anden i 1927 - begge i "Bedre Byggeskik" - "Heimatschutz«-stilen!

foretaget en udstykning af nogle af godsets jorder, og 27 nye husmandsbrug blev oprettet. Gennem gamle dokumenter havde man fået god besked om den gamle landsby, Skovhuse, og den nye bebyggelse fik derfor navnet Skovhuse.

Der er kønt i Skovhuse. Nord for byen findes ret store skove, og mod vest går landet ned mod det smukke Alssund, på hvis vestlige bred Sottrupskov strækker sig. Mod øst og nord beskylles landet af Augustenborg fjord. Om marker og huse strækker sig levende hegn, og man får indtryk af at befinde sig på en meget frodig og frugtbar egn. Her ude på halvøens nordvestside var det, at prøjserne sejlede over Alssund fra Sottrupskov til Arnkil om natten den 29. juni 1864. Langs veje og markskel finder man mange krigergrave og mindesten fra kampene den 29. juni. De minder os om den tapre og fortvivlede modstand, vore landsmænd viste en fuldstændig overlegen fjende.

Landsbyens bebyggelse er meget spredt, og hele befolkningen er beskæftiget ved landvæsenet. Skolen, der blev bygget i 1927 kort efter udstykningen, ligger meget centralt, længste skolevej $11 / 2-2 \mathrm{~km}$. Skovhuse skole ligger i Ulkebøl sogn, der er et temmeligt stort sogn med ca. 3.000 indbyggere.

\section{Skolens indretning}

Der hører et temmelig stort stykke jord til skolen, ca. $11 / 2$ td. land. Jorden måler $80 \mathrm{~m}$ på hvert led (se fig.). Skolens længderetning er syd-nord. Facaden 
vender mod øst ud til landevejen. Undervisningslokalerne findes i bygningens nordlige ende, og i den modsatte ende findes lærerens lejlighed.

Skolen har to klasseværelser, hvoraf hvert har 4 store vinduer henholdsvis mod øst og vest. Værelsernes størrelse er $8 \times 6 \times 31 / 2 \mathrm{~m}$. Da der kun er en lærer ansat ved skolen, benyttes kun klasseværelset mod øst. Det andet står tomt, men benyttes dog om vinteren som gymnastiksal.

Vest for skolen $(8 \mathrm{~m})$ ligger et baghus med hestestald, brændselsrum, WC og hønsehus. Imellem dette hus og skolen står pumpen, hvor børnene kan drikke vand og vaske hænder. Skolepladsen ligger nord for bygningerne. Den er bevokset med græs og har en størrelse af ca. $30 \times 60 \mathrm{~m}$.

I sognet findes der foruden i Skovhuse skoler i Ulkebøl by og i Kær. Ulkebøl skole er syvklasset, medens skolen i Kær er en almindelig to-klasset landsbyskole.

Klasseværelset, der benyttes, vender mod øst og er stort og rummeligt. De 4 store vinduer giver sol hele formiddagen. Vinduerne er forsynede med rullegardiner. Der findes en stor kakkelovn ved den vestlige væg. Fra loftet hænger to elektriske lamper. Væggene er malede i et par meters højde med en dyb mørkerød farve. Den øverste del af væggen er gul og loftet er hvidtet. Dørene er malet med en grålig farve, og gulvene ferniserede.

På væggene hænger kun få billeder. På den ene endevæg hænger et par smukke dybtryk. Det ene er af en gammel købstadbygning, Apostelgaarden i Næstved. Det andet forestiller et østdansk landskab. Desuden hænger nogle enkelte kartonnerede, uindrammede billeder på de andre vægge. Et er af Dalgas, et andet af Frihedsstøtten i København.

Skolen har ni nye to-mands borde af samme model som øvelsesskolens nyeste. Dog findes der ikke skuffer i bordene, kun hylder under bordpladen. Foruden disse nye borde har skolen nogle meget gamle, som står forrest $\mathrm{i}$ klassen. Der er tre fire-mands og to to-mands borde af de gamle. Bordene er ordnet $\mathrm{i}$ to rækker med fem to-mands på den ene side af gangen og resten på den anden. Katederet har form som et skrivebord med skuffer og skabe, og det står på en forhøjning.

Bag ved katederet er anbragt en stor vagtavle, hvis ene ende er inddelt $i$ kvadrater, som er påmalede. Denne ende af tavlen anvendes både til regning og skrivning. Ved siden af katederet står en fritstående tavle, som kan vendes og benyttes på begge sider. Dette er meget praktisk, idet man på den ene side kan gemme noget, man har skrevet i en time, til senere anvendelse. Begge tavlerne er matsorte og forsynede med træramme. Langs klasseværelsets ene sidevæg står to store skabe. I det ene findes de bøger, som anvendes i undervisningen, samt hefter til skrivning, regning og dansk. I det andet skab opbevares en billedsamling, som særlig anvendes ved småbørnenes hjemstavnsundervis- 


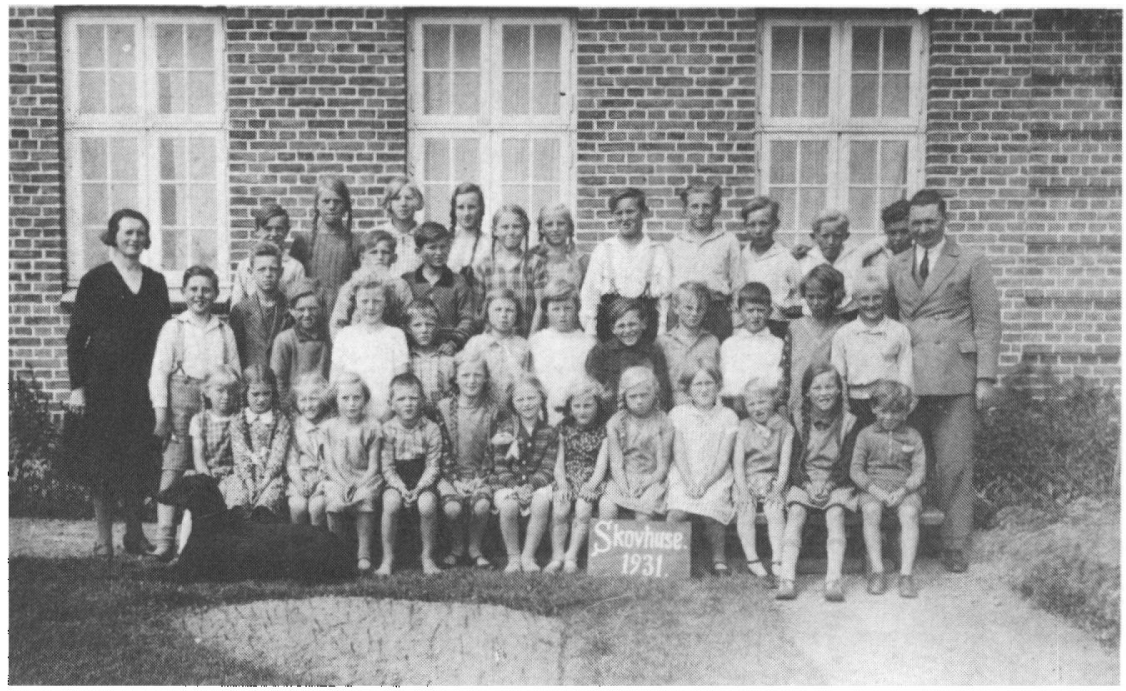

Larer Poul Poulsen og hustru Marie ("Midder) og bernene i Skovhuse skole 1931. Foto i Lokalhistorisk Arkiv, Ulkebol.

ning. Tillige findes i skabet børnenes tegnehefter og maleredskaber samt de geografiske kort, hvoraf ingen hænger fremme til stadighed. Af andet materiel kan nævnes kugleramme, globus samt skolens stolthed, et nyt lysbilledapparat, som kan anvendes både til films, glasbilleder og almindelige billeder fra bøger, aviser o.s.v. Af gymnastikredskaber findes en bom med tilhørende ribber, en buk, springstøtter med snor samt en håndbold.

\section{Bornene og undervisningen}

Der er 35 børn i skolen. Deraf går de $23 \mathrm{i}$ anden og $12 \mathrm{i}$ første klasse. Børnene er $\mathrm{i}$ alderen fra 7-14 år. De tre yngste årgange fra 7-10 år går $\mathrm{i}$ første klasse, resten $i$ anden.

Børnene er gennemgående normalt begavede. Dog ligger i yngste klasse gennemsnittet lidt under det normale. Børnene var i begyndelsen meget tilbageholdende, men efter kort tids forløb tog de interesseret og flink del i arbejdet og samtaler. Der tales dialekt i timerne og på legepladsen. Læreren taler dog rigsdansk, og børnene opøves også $\mathrm{i}$ at udtrykke sig på rigsmålet. Læreren taler dog ofte dialekt med de små, som det især kniber for at udtrykke sig på rigsdansk. Børnene er lette at disciplinere og som regel meget opmærksomme i timerne og ivrige efter at komme ind efter frikvarteret. Tonen og forholdet mellem børnene er god. Morsomt er det at se de store børn ganske uopfordret gå hen at hjælpe de små ved deres arbejde eller at høre de yngstes glæde over 
en af kammeraternes fremgang. De yngste vil gerne fortælle læreren deres små selvoplevelser. I frikvarteret spiller børnene både store og små med forkærlighed håndbold.

Børnene er mere tilbageholdende og gennemgående lettere at disciplinere end børnene i byerne, et forhold, som vel nok hænger sammen med landsbylærerens større autoritet, som grunder sig på hans hele stilling $\mathrm{i}$ befolkningen. For mange af landsbybørnene, der ofte må tage tidligt fat med arbejdet hjemme, er skoletiden og samværet med kammeraterne ofte en behagelig afveksling, som vel også nok gør sit til, at de er lettere at disciplinere.

I Skovhuse skole er børnene delt i to klasser. Om sommeren begynder ældste klasse hver dag skolen $\mathrm{kl}$. 7, og deres skoledag ender kl. 12 hver dag undtagen torsdag, hvor klassen har fri kl. 10. Ældste klasse har altså fri hver eftermiddag. Pigerne har dog håndgerning fra 1-3 tirsdag eftermiddag. Yngste klasse går i skole mandag og fredag eftermiddag fra $12,30-4$ samt de to sidste timer torsdag formiddag. Desuden møder de sammen med ældste klasse tirsdag fra 8-12, onsdag 10-12 og hele lørdag formiddag (se timeplanen). Alle undervisningstimer er på $50 \mathrm{~min}$. Om vinteren er ordningen $\mathrm{i}$ det væsentlige den samme, blot er undervisningstiden rykket en time fremad. Børnene har to gymnastiktimer ugentlig. Om sommeren benyttes de til boldspil på skolepladsen eller, når vejret er godt, til badning. Om vinteren drives gymnastikken i det tomme klasseværelse.

Klasseundervisningsprincippet er det fremherskende, dog må her med »klasse « forstås »hold«. Både den udfindende og meddelende metode anvendes, som naturligt er, den sidste særlig ved åndsfagene. Børnenes selvvirksomhed tages i nogen grad i brug for de større børns vedkommende. F. eks. benyttes meget et system bestående af små kartonkort, som er påtrykt opgaver i spørgsmålsform. På kortene findes for nogle opgavers vedkommende, f.eks. historiske, også kilde-angivelser. Hvert af børnene (kun de store) får så udleveret et sådant kort og udarbejder så på egen hånd en skriftlig besvarelse. En sådan opgave kan godt beskæftige et barn i flere timer. Læreren arbejder så imens med de mindre børn. Også på anden måde tages børnenes selvvirksomhed $\mathrm{i}$ anvendelse. F. eks. laste de store børn på egen hånd $\mathrm{i}$ et hefte af Th. Roust om H.P.Hanssen. Dog læste de også enkelte afsnit af bogen som højtlæsning.

Det manuelle arbejde indtager en meget ringe plads i undervisningen. Der er dog på skemaet afsat en time ugentlig til tegning. I denne făr børnene ofte lov til at tegne og farvelægge selvvalgte modeller, og flere af dem kunne også fremvise mange nydelige arbejder $i$ deres hefter. 


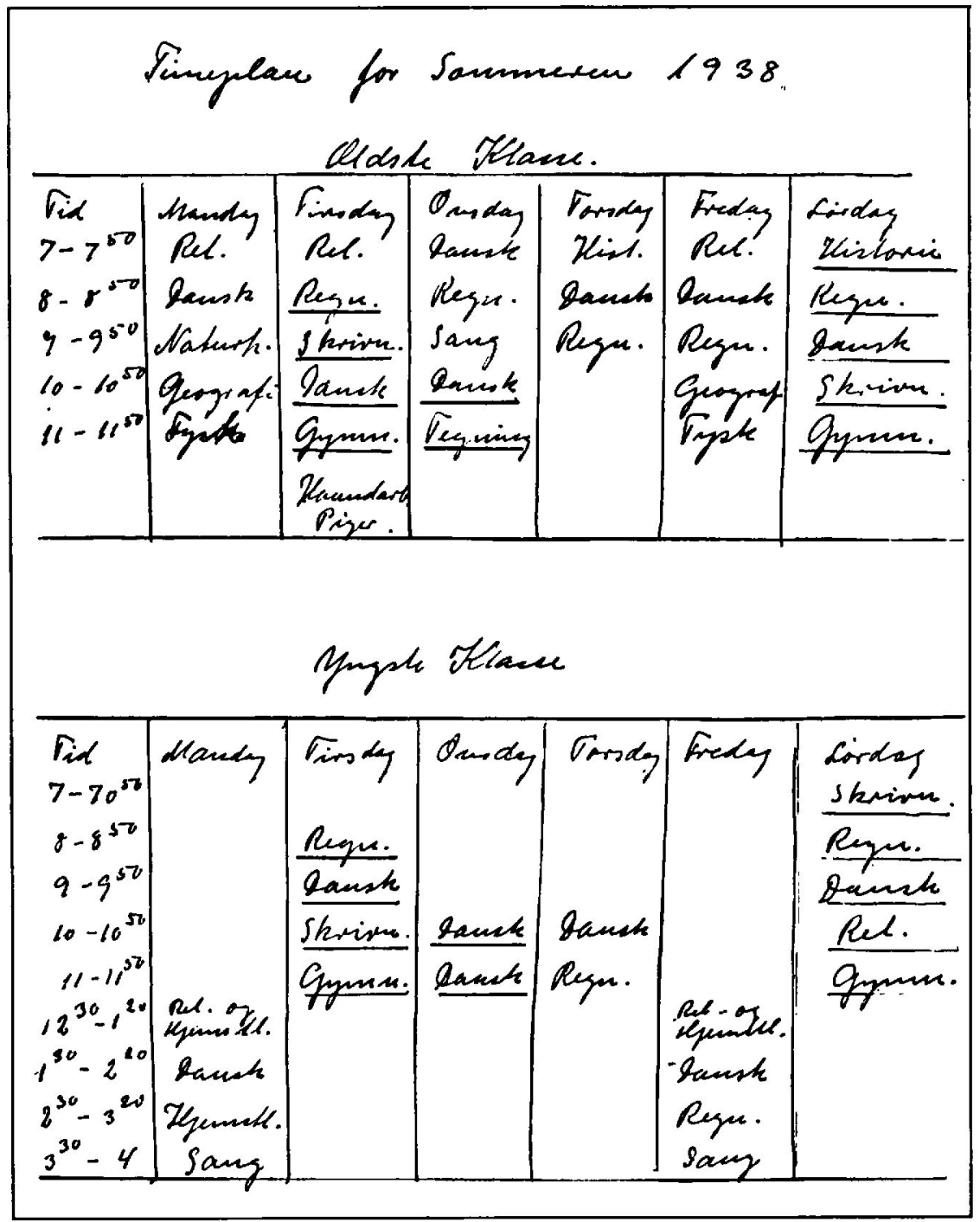

De understregede timer angiver de timer, hvor begge klasser er samlede.

Ved regneundervisningen anvendes 1., 2., 3. og 4. hefte af Landsbyskolens Regnebog ved Fr. Friis-Petersen, J. L. W. Jessen og H.P.H. Novrup, samt nogle tillægshefter. Af hjælpemidler findes kugleramme og meterstok.

Hver af de to klasser er inddelt $i$ hold. I yngste klasse er der tre hold. Første hold anvender 1 . hefte af regnebogen. Andet og tredje hold regner henholdsvis 
række A og rakke B af regnebogens andet hefte. Hovedregning for de to hold er fælles. I ældste klasse er der fire hold. De to yngste hold regner i regnebogens 3. hefte og har hovedregning sammen. De to ældste hold benytter på samme måde 4. hefte af regnebogen. Dog er ældste årgang færdig med regnebogen og regner i nogle tillægshefter, men de har hovedregning sammen med næstældste årgang.

To timer ugentlig, nemlig tirsdag og lørdag, har første og anden klasse regning sammen. På næste side er vist en skematisk fremstilling af en regnetime i klasserne hver for sig og en, når klasserne er sammen. Læreren kontrollerer som regel selv resultaterne. Undertiden sker kontrolleringen også ved, at et af de ældste børn, når det er færdig med sine egne opgaver, får facitlisten og kontrollerer de andres. Hvis et barn ikke bliver fardig med de opgaver, som er beregnet til timen, regnes resten færdig hjemme. Bliver nogen derimod færdig før timens udløb, får de lov til at beskæftige sig med tegning eller læsning, blot de ikke forstyrrer de andre i deres arbejde.

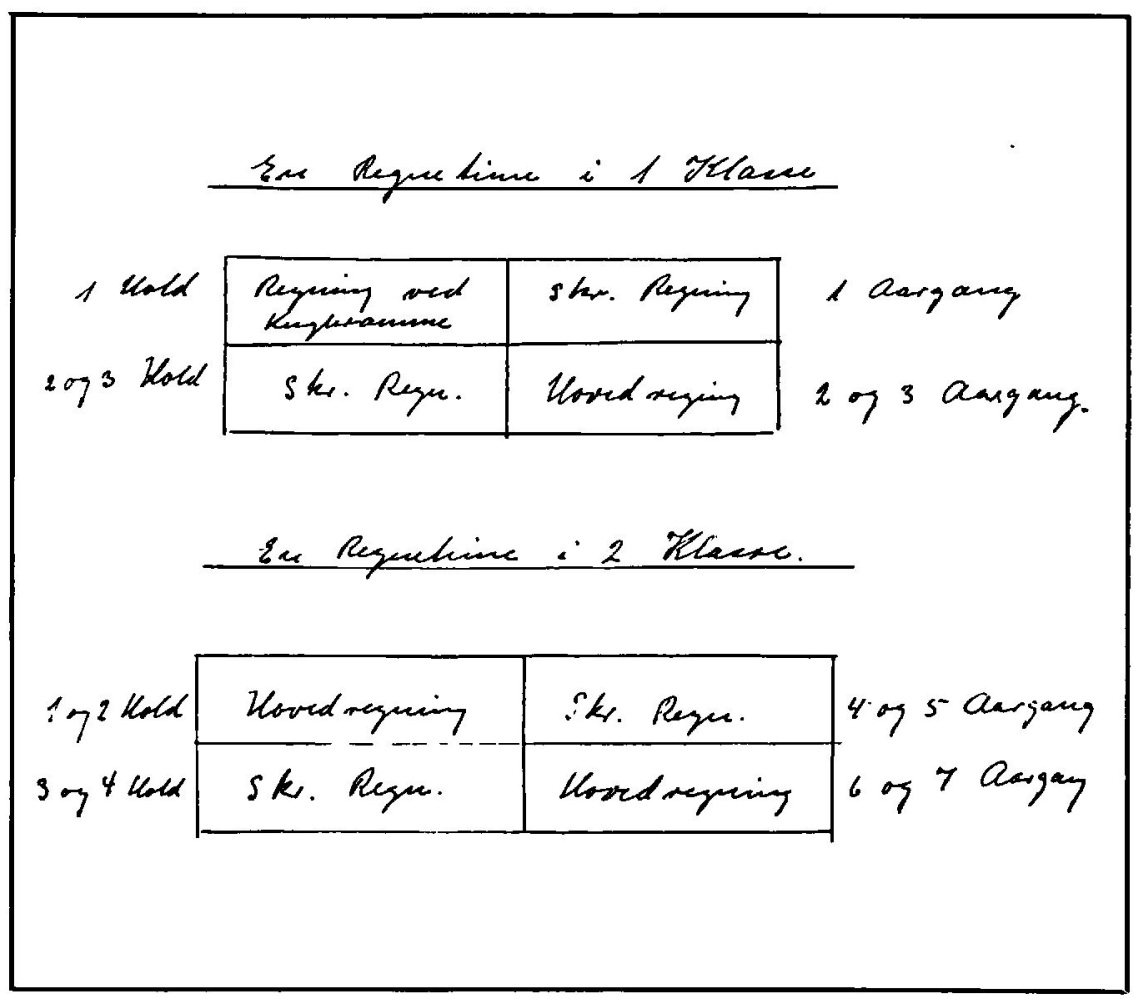




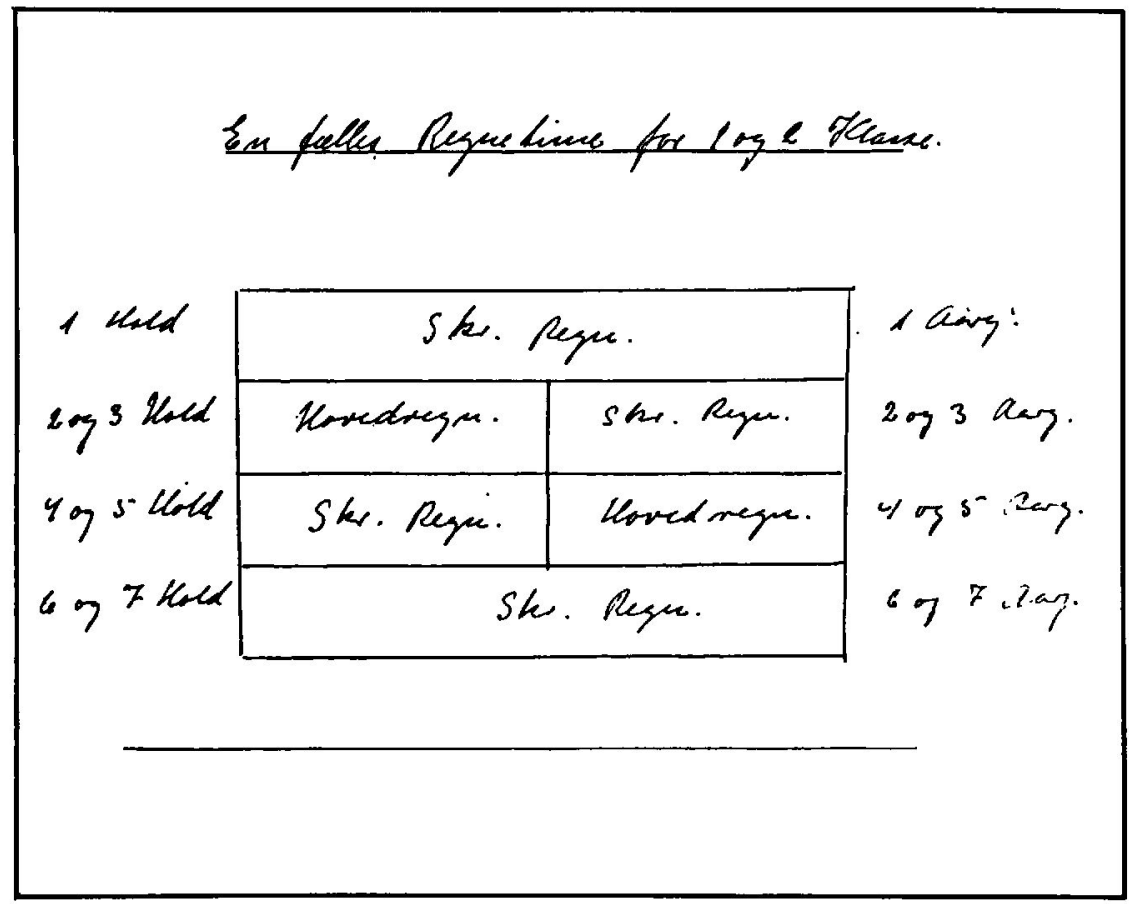

Skole og hjem

Læreren har på forskellig måde forbindelse med hjemmene. Blandt andet gennem skolesparekassen. De penge, som børnene sparer sammen i ugens løb, afleveres til læreren hver lørdag i en bestemt time. Hvert barn har en sparebog, hvori de enkelte beløb straks indføres af læreren. Læreren fører desuden bog over sparebeløbene, som en gang hver måned indsættes i sparekassen. Børnene får så ved udgangen af skolen det opsparede beløb udbetalt med renter og renters rente. Både børnene og hjemmene er meget interesseret i skolesparekassen. I skoledistriktet findes også en spareforening, »Julens Glæde«. I denne er læreren kasserer, og nogle af skolebørnene har det hverv en gang ugentlig at samle penge ind $\mathrm{i}$ alle hjemmene. Pengene afleveres til læreren, som indsætter dem i banken. De opsparede penge udbetales hvert år lige før jul.

Hvert år ved eksamen møder nogle forældre op og overværer børnenes præstationer. Som regel er hvert hjem, der har et barn i skole, repræsenteret. Hvert år afholdes også julefest i skolen. Ved denne lejlighed opfører børnene en lille komedie. Både forældrene og gamle elever deltager i denne fest, og lærerens beværter alle deltagerne med kaffe. 


\section{Bevtoft skole ${ }^{7}$}

\section{af Anna Schroder}

I tiden fra den 10. til den 24. juni 1940 opholdt jeg mig i Bevtoft for at følge undervisningen i denne landsbyskole.

Bevtoft sogn, som ligger i Haderslev østeramt, er et stort sogn. Dets indbyggerantal er ca. 1200. Sognet er delt i fire skoledistrikter, hvoraf Bevtoft er det største. Bevtoft skoledistrikt samler sig om Bevtoft by og Hjartbro. Egnen omkring Bevtoft er sandet og tør. Der findes en del hedeflader og granplantager på egnen. Ude ved Hjartbro ligger en bakkeø. Her er jorden bedre, og den er for en stor del bevokset med løvskov, Hjartbro skov. Gennem Bevtoft by løber Gjels å, og omkring den er der en del sump og sur eng. Ved åen er der fra gammel tid anlagt en mølle. Jorden er godt opdyrket. Der er gjort meget for at hjælpe på den magre jord. Der er merglet, og plantet læbælter. På Bevtoftegnen dyrkes en mængde kartofler, som afsættes til kartoffelmelsfabrikken i Toftlund. Sognets beboere består for største delen af små gårdmænd og husmænd. Dog findes der en del større gårde. Den øvrige befolkning er landarbejdere i Bevtoft by. Selv om befolkningen socialt viser store forskelle, er den dog på andre områder en enhed. Nationalt set er egnen meget vågen. Det er Krügers gamle sogn, og det har sat sit spor i sognet. Ved sidste folketingsvalg d. 3. april 1939 stemte i Bevtoft 616 dansk og kun 10 tysk. Den tyske stemmeprocent bliver ca. $1,63 \%$. Vi ser heraf, at Bevtoft er et næsten rent dansk sogn, men overalt i Sønderjylland vil der jo være et større eller mindre tysk mindretal. Befolkningen er ikke alene dansk, når der skal stemmes, de er sig deres danskhed bevidst, også til daglig. Forsamlingshuset er samlingssted for egnens befolkning. Man er sikker på stor tilslutning, når der er kulturelle og nationale foredrag, og naturligvis møder de fuldtalligt på de store nationale festdage, Afstemningsdag, Genforeningsdag, Dybbøldag, Grundlovsdag osv.

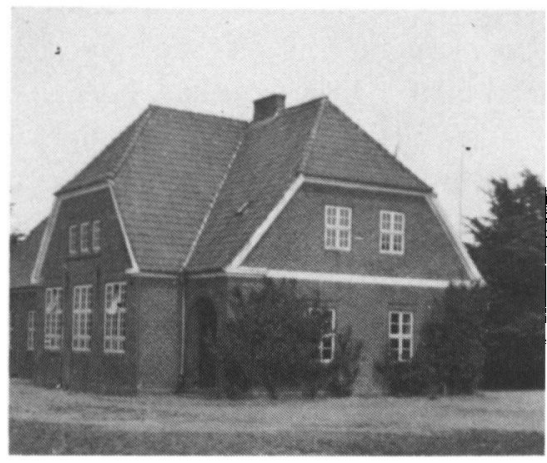

Bevtoft skole fotograferet af Anna Schroder $i$ 1940. 
Ude ved de velholdte gårde og huse går flaget til tops på disse dage og på en hver anden dag, hvor der er anledning til at vise sit danske sindelag. Som sagt er gårde og huse velholdte. De store gårde er præget af velstand, de mindre gårde og husmandssteder af orden, flid og stræbsomhed.

Religiøst er egnen ikke præget af nogen bestemt kirkelig retning. Præsten er indremissionsk, og selv om disse ikke er i flertal, er de dog de mest vågne. Der findes en del grundtvigsk prægede hjem på egnen.

\section{Skolens indretning}

Skolen ligger i den vestlige del af landsbyen omgivet af læbælter på alle sider. Ved siden af skolen ligger et lille anlæg med genforeningsstenen. Over for skolen på den anden side Toftlund-Vojens-landevejen ligger kirken og præstegården. Skolen er en køn rød murstensbygning med rødt tegltag. Den er som mange af Sønderjyllands skoler bygget i 1912, men den bærer ikke udadtil præg af tysk byggestil. Indvendig er den stor og rummelig, især lærerens lejlighed. Foruden skolebygningen findes et udhus med brændselsrum, toiletter osv. Legepladsen er $3500 \mathrm{~m}^{2}$. Omkring skolen er der grusplads, længere oppe er der græsmark til boldspil og leg. Pladsen ligger lunt og godt omgivet af læbælter til alle sider. I det vestlige hjørne nede ved skolen findes et tysk gymnastikredskab, en slags bom af jern. Bag udhuset findes en vinkelformet tilflugtsgrav med plads til alle børnene. Graven er dækket af brædder og sand, og der er nedgang $\mathrm{i}$ begge ender, så der bliver ingen luftmangel. Børnene er opøvede i i ro og orden at gå derned og tage opstilling. Der er også en drikkefontæne og vaskekumme.

Skolen består af to klasseværelser, der er lige store. Målene er $8,65 \mathrm{~m}$ x 6,20 $\mathrm{m}$. Gulvfladen bliver $53,63 \mathrm{~m}^{2}$. Højden er $3,55 \mathrm{~m}$. Rumfanget bliver i hver klasse $190,387 \mathrm{~m}^{3}$. Da der højst opholder sig 36 børn i klassen, får hvert barn $5,29 \mathrm{~m}^{3}$ luft og 1,49 $\mathrm{m}^{2}$ gulvflade. Altså lovens krav om $2 \mathrm{~m}^{3}$ luft og 1,4-1,5 $\mathrm{m}^{2}$ gulvflade pr. barn er rigelig opfyldt. På den ene langside findes tre store vinduer, mål $1,70 \mathrm{~m} \times 2,25 \mathrm{~m}$. Den samlede vinduesflade bliver $11,5 \mathrm{~m}^{2}$. Forholdet mellem gulvflade og vinduesflade bliver ca. 1:5. Loven kræver 1:7. Alle disse mål og forhold er fælles for de to klasseværelser.

I ældste klasse findes 19 to-mands borde. De fleste er af tysk konstruktion fastspændt til gulvet og det foregående bord. De står, så børnene får lyset fra venstre. For endevæggen er der en forhøjning med kateder, og bag dette hænger vægtavlen $(3,45 \times 0,75 \mathrm{~m})$. Desuden fandtes to skabe. Det ene til børnenes arbejder, håndbøger og materialer. Det andet til kort og billeder. De fleste af disse stammede fra tysk tid og brugtes ikke meget. I et nyt faststående dobbeltskab med skydelåger fandtes bogsæt, dels skolens egne, dels fra skolecentralens vandrebibliotek. 


\section{Grund plan over Bertoft Skole.}

Maral 1:100.
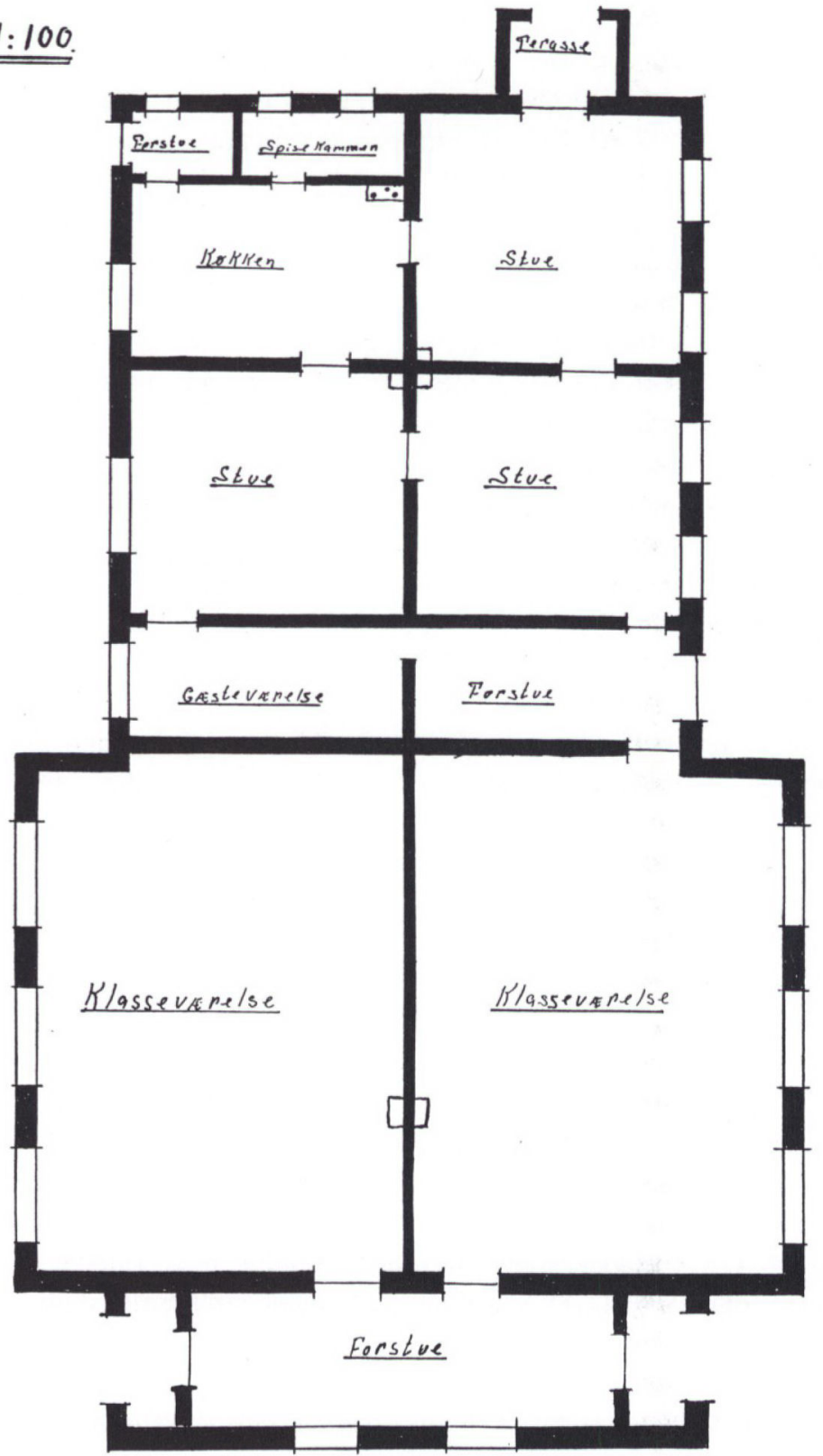
Væggene var i panelhøjde ca. 1 1/2 m op malet gule, den øvrige del og loftet var hvidkalket. I loftet hang tre hvide lampekupler. På væggene hang 11 billeder af sønderjyske førere. Foruden disse var der billeder af kongen og dronningen, Genforeningsbillede, billede af Chr. 9, og så fandtes der et smukt billede af afd. amtsskolekonsulent Ludwig Mortensen. Endvidere var der to nye landkort af Afrika og Australien samt et gammelt tysk barometer. Vinduerne var forsynet med hvide kapper og sorte rullegardiner, så klassen kunne gøres mørk til fremvisningen af lysbilleder. Skolen ejede et fint nyt lysbilledapparat. Der var ikke centralvarme, så klasseværelserne var forsynet med en stor sort kakkelovn. Vindueskarmene var gullakerede, og i alle karmene stod pæne grønne potteplanter. Det var en lys og venlig klasse at træde ind i om morgenen, når solen skinnede ind af vinduerne.

Yngste klasse så ud omtrent som ældste klasse. Her fandtes 17 to-mands borde, alle stammende fra tysk tid. Bag katederet hang vægtavlen $(3,45 \mathrm{~m} \mathrm{x}$ $0,75 \mathrm{~m}$ ). Det er lærerindens tavle, men børnene har deres egen tavle. Den sidder så lavt, at de kan nå at skrive og tegne på den, og hvis der er noget børn kan lide, er det at få lov til at benytte en tavle. Målene for denne tavle er $3,50 \times 0,50 \mathrm{~m}$. Så findes der den uundværlige kugleramme. Børnene kappes om at få lov at komme op og regne med de store rode og sorte kugler.

I et skab gemmes børnenes arbejder og materiale som regnepinde, farveblyanter, svanemapper osv. I en billedkasse findes bibelske billeder, udpræget barnlige tegninger, som børnene er meget optaget af at se. Desuden findes en del billeder, der bruges til iagttagelse. Det er gamle billeder fra tysk tid med dyr og børn, ikke noget med cykler, biler, byer og lignende. Desuden findes et bord, som pigerne bruger til håndgerning, når de klipper og syr på maskine. Skolen ejede én symaskine, som de så måtte klare sig med ved hjælp af lærerindens. Så fandtes der et skab, som egentlig ikke kom skolen ved, et biblioteksskab. Der opbevaredes bøger fra Haderslev Centralbibliotek. Hver anden måned fik man nye bøger. Lærer Madsen og frk. Holm tog sig af udlånet.

Væggene herinde var ikke nær så fint smykket som i den anden klasse, men til gengæld havde de skolens fineste billede, en reproduktion af Fritz Sybergs billede "Børn begraver en fugl«. Det var børnene meget optaget af, især når man fortalte dem om billedet og lod dem fortælle om deres egne oplevelser med fugle. Så fandtes der også her et billede af kongen foruden to små eventyrbilleder. I vindueskarmene stod der blomster. I den ene urtepotte havde de et lille kastanietræ. Det var børnene meget optaget af. Det var da virkelig spændende at have et rigtigt lille træ stående $\mathrm{i}$ vinduet. 


\section{Bornene}

Inden for disse rammer går skolen sin daglige gang. ... Bevtoft skole er en treklasset landsbyskole. I øjeblikket går der 85 børn i skole. Børnetallet har i de senere år været meget konstant. Børnene er i klasserne fordelt således:

ældste klasse, 35 børn: $\quad$ ældste hold 10 børn

mellem hold 6 børn

yngste hold 19 børn

mellemste klasse, 27 børn: ældste hold 16 børn

yngste hold 11 børn

yngste klasse 23 børn:

aldste hold 13 børn

yngste hold 10 børn.

Disse 85 børn kommer fra vidt forskellige hjem. En del kommer fra gårdmands- og håndværkerhjem, men største delen kommer fra mindrebemidlede hjem, husmands- og arbejderhjem. Dette forhold skyldes dels, at der i sognet findes mange husmænd og arbejdere, og dels, at de som regel har mange børn, hvad der ikke er tilfældet for gårdmandshjemmene. Det er som regel ikke fra disse store børneflokke, de flinkeste og mest velbegavede børn kommer. Denne regel gør sig da også gældende her, og det sætter sit præg på skolen som helhed. Børnene er meget stærkt prægede af hjemmene. Af deres klædedragt kan man næsten bedømme hjemmet, ikke alene hvad velstand angår, men også med hensyn til orden, renlighed og interesse for børnene ...

Jeg spurgte en dag børnene, om hvad de foretog sig uden for skoletiden. Det var kun et fåtal af børnene, der svarede, at de legede. De fleste svarede, at de hjalp mor, passede små søskende eller var med i marken og mosen. Der bliver for de flestes vedkommende ikke megen tid til leg, men man må ikke tro, at de føler arbejdet som en byrde, tværtimod: de går op i det med liv og lyst, især drengene.

Men børnenes naturlige trang til at lege udfoldede de til gengald i fuldt omfang i frikvartererne. De var igang fra det øjeblik, de blev sluppet ud, og til klokken igen kaldte dem ind. Der var ikke noget med at sole sig i græsset eller spadsere op og ned af pladsen. Nej, der var fart over hver eneste lille pige og dreng. Som alle steder var legene periodiske. Medens jeg var i Bevtoft spillede de store drenge fodbold eller legede "fanger « fra den ene ende af pladsen til den anden.... Krig legede de slet ikke og talte næsten ikke om det. Kun ved særlig store begivenheder kunne man høre dem tale om det. Af læreren fik jeg at vide, at de lige da krigen var brudt ud, legede tyskere og englændere, men det holdt hurtigt op, og de havde ikke taget det op siden.

De små drenge fordrev tiden $\mathrm{i}$ det gamle gymnastikredskab. Her tumlede 
de sig hele frikvarteret med at klatre i bardunerne, slå kolbøtter og snurre rundt, og hvad man ellers kan finde på i et sådant redskab. Hjørnepladsen på bommen var den fineste plads. Den gav man ikke godvilligt afkald på, når man først havde erhvervet den. De kunne nok komme lidt op at skændes om denne fornemme plads, men i reglen enedes de pænt om at lege på bommen.

De store piger spillede bold, og de små piger hoppede i paradis. Det er ellers en forårsleg, men nu var de kommet i gang med det, og så blev de ved, til en fandt på noget nyt.

Det er alle sammen meget typiske frikvarterlege, men til andre tider legede pigerne ovre i læbæltet. De byggede »hjem« af alt, hvad de kunne finde. De kom tidligt om morgenen og havde papirstrimler, glasskår, dåser osv., og så legede de »far, mor og børn « i alle frikvartererne. Det var morsomt at høre dem bruge tonen, som de kendte hjemmefra, i deres leg. De talte sønderjysk, som de gjorde hjemme, på pladsen og til dels også i klassen. En »skole« havde de også, og her talte så vel »lærerinde« som »børn« »fint«, det vil sige: rigsdansk. Der kunne gå lang tid, hvor det var deres eneste leg. Men når først drengene blev nysgerrige, drillede og ødelagde, holdt det hurtigt op. Drilleri var ellers ikke noget man hørte meget til... En enkelt dreng var fra et tysksindet hjem, og ham gik det nu og da ud over. Men han stod aldrig uden for legen. De legede alle med ham, men kom han lidt på kant med de andre, måtte han høre for det tyske. Men det prellede af, og næste frikvarter havde begge parter glemt striden og legede sammen igen.

Pigerne hørte man aldrig drille hinanden indbyrdes. De legede lige godt sammen, enten de var kloge eller ej, enten de var velklædte eller dårligt klædte. Jeg undrede mig over, så lidt standsforskel de viste. Når man har set, hvorledes

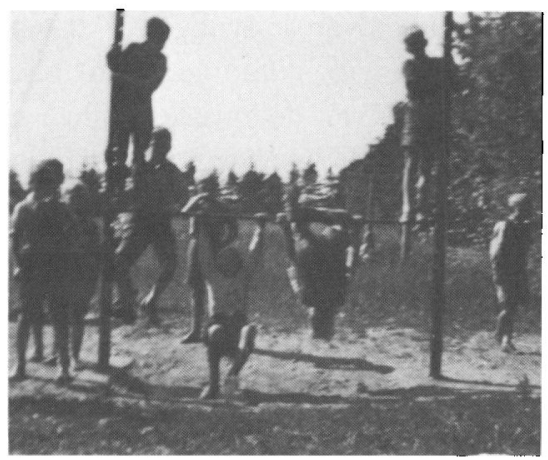

Drengene i bommen

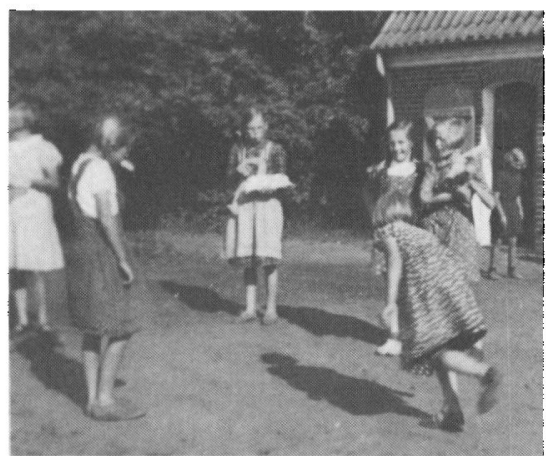

Pigerne hopper i paradis 
børn i en byskole f.eks. kan være ubarmhjertige mod mindrebemidlede kammerater, undrede man sig over at se dem lege pænt med hinanden alle som en. Det samme bemærkede jeg, da vi var på skovtur med yngste klasse. Da vi legede "to mand høj«, stod pigen $\mathrm{i}$ den fine kjole lige så gerne sammen med en $i$ en snavset kjole som sammen med en ligestillet.

På en tur til Haderslev med de store børn måtte man uvilkårligt lægge mærke til den gode og af børn stilfærdige optræden, som de udviste, ikke mindst drengene, der ofte kan være vanskelige at tumle på en tur. Der var ikke noget med at køre bort eller råbe til andre børn, der råbte efter dem. De havde fået deres instrukser $\mathrm{i}$ forvejen, og de blev overholdt. Var der en, der prøvede at bryde ud, skulle de andre nok holde ham tilbage. På grund af de særlige omstændigheder måtte vi kun cykle 6 sammen. Jeg havde 6 drenge at holde styr på, men det voldte ingen vanskeligheder. Jeg kørte foran og morede mig over, hvad de talte om. De lagde mærke til alt, hvad de kom forbi. Bemærkede at korn og roer stod godt, talte husnumrene i Vojens og legede med cykleklokkerne....

Den tid man havde mest lejlighed til at iagttage børnene var i undervisningstiden, og her var de som helhed tunge. Lærer Madsen fortalte, at det var sjældent, de havde et hold børn, der var så tunge .... Dette prægede deres skolegang, den var for drengene kun en pligt, og de havde ikke gnist af interesse for skolearbedet. Pigerne var gennemgående mere flittige og interesserede $\mathbf{i}$ skolearbejdet, men de var som helhed også bedre begavede ....

Børnene var stærkt præget af deres miljø både hvad opførsel, talemåde og interesse angik. Nogen særlig videbegærlighed om det, der lå uden for deres egen kendte verden, udviste børnene ikke. Denne spørgen om alt muligt, som man ofte træffer hos børn, var der kun lidt af her. Jeg spurgte en dag drengene, om hvad de ville være. Største delen svarede landmænd. Hele deres interesse lå hjemme på gården eller bedriften. Mange gange var de tvunget til at tage del $\mathrm{i}$ arbejdet, og de gjorde det med interesse. De ville ikke finde på at blive andet end landmænd. Men trods deres tunghed var de rare og villige til arbejdet, og efterhånden som man lærte dem at kende, blev de også fortrolige og tillidsfulde.

\section{Undervisningen}

Som før omtalt er Bevtoft skole treklasset. Da der kun er to lærerkræfter, er der altid kun to klasser i skole af gangen. Skoleåret er delt i et sommer- og vinterhalvår. Yngste klasse er i skole hver dag, både sommer og vinter. Mellemste klasse har kun fem skoledage om ugen hele året, og ældste klasse har om sommeren fire dage om ugen og om vinteren fem dage om ugen. Ved denne 
skolegangsordning opnår man, at de store børn får en del tid til hjælp i hjemmet.

Undervisningen hviler i de fag, hvor det er muligt, på lærerens fortælling og forklaring af stoffet. Overhøring af børnene foregik hovedsagelig ved at læreren stillede spørgsmål,og børnene svarede. Børnene havde som sagt vanskeligt ved at udtrykke sig, så det blev ikke til meget for børnene, hvis de skulle fortælle.

Undervisningsformen var dels klasseundervisning i religion, historie, geografi og naturfag osv., dels undervisning $i$ hold i dansk, regning, skrivning og tegning. Børnene var delt $\mathrm{i}$ hold efter alderstrin, således at der $\mathrm{i}$ de tre klasser blev 7 hold: 2 i første, $2 \mathrm{i}$ anden og 3 i tredje klasse svarende til de 7 folkeskoleklasser i en købstadordnet skole. Holdene betragtes også som klasser. Kan en elev ikke følge med sit hold, bliver han siddende i samme hold, medens de andre rykker op i næste. Hverken af børn eller forældre er det velset at blive $i$ et hold mere end et år.

Lareren kan jo kun arbejde med ét hold af gangen, det andet hold arbejder imens selvstændigt uden ledelse af nogen art, og det går udmærket. Børnene arbejder støt og roligt, hvad enten det nu er stillelæsning eller skriftligt arbejde, indtil læreren blev færdig med det andet hold og tog sig af dem. Når man aldrig har set en landsbyskole arbejde, forbavsedes man over, at børnene arbejdede så godt, som de gjorde, samtidig med, at de andre børn og læreren talte om noget andet. Fra byskolen er man jo vant til, at der er ro, når man regner, skriver eller læser stillelæsning. Men her generede det ik'se t srnene, at de andre regnede højt, medens de selv regnede skriftlig regning, eller at der var højtlæsning, når de læste stillelæsning osv. De arbejdede lige godt endda.

Jeg vil i det følgende gøre nærmere rede for undervisningen i nogle af de forskellige fag.

Skriftlig dansk. Her arbejdedes der efter "Det danske Sprog« tilrettelagt for landsbyskolen af S.P.Fredebo og Ebbe Stephansen. Den bestod af en kortfattet sproglære, hvortil der svarede et lille tekststykke, som børnene skrev af og analyserede ved at sætte tegn under de forskellige led. Bogen var ordnet $\mathrm{i}$ "uger«. Til hver uge var der en diktat med forberedelse. De ord, der stod $\mathrm{i}$ forberedelsen, skrev børnene af, delte dem i ordklasser og bøjede dem. Børnene fik på den måde stor færdighed, ikke alene $\mathrm{i}$ at stave, men også $\mathrm{i}$ at bøje alle ordene. Det øvrige stof i "ugen« varierede med genfortælling, stilopgaver, sproglære, breve o. lign. Børnene fik da lært at bruge sproget også til praktiske ting. I nogle diktater var der samlet en mængde fremmede ord fra det daglige liv. Børnene fik samtidig lært at stave ordene og fik lært deres betydning.

Mundtlig dansk. Her bruges "Den nye Læsebog for Landsbyskolen«. Hjem- 
melæsning er der ikke noget, der hedder. Børnene får et stykke for, og det læser de stillelæsning på, medens læreren er beskæftiget med det andet hold. I næste dansktime har de så højtlæsning. Hovedvægten lægges på, at børnene læser flydende og rigtigt, først så bliver der tid til at rette på stemmeføring og sprog. Med det sidste kniber det meget, da børnene er vant til altid at tale sønderjysk. Oplæsningen er præget af det, eller også læser de næsten bogstavret, så det bliver unaturligt. Som hos de fleste børn, der læser godt, kniber det at få det langsomt og tydeligt læst. I tilknytning til læsningen taler lærer Madsen lidt med børnene om stykket, de har læst og stiller spørgsmål og prøver at lade dem finde ud af billedsprog, betydning osv. i stykket. Bogens stof er ordnet efter tidsalder, således at børnene gennem lærerens fortælling om de forskellige digtere får lidt at vide om hovedtrækkene i dansk litteratur. I forvejen ved børnene lidt fra deres Danmarks historie.

Småbornsundervisning $i$ dansk. I yngste klasse går mundtlig og skriftlig dansk sammen. Børnene lærer at læse efter ordbilledmetoden. Tidligere brugte frk. Holm lydmetoden efter Claus Eskildsens bog "Ole Bole«, men er nu gået over til "Svanemappen« og "Svanebogen«. Det er første år, det er prøvet, så frk. Holm vidste endnu ikke rigtig, hvordan det ville falde ud. Ældste hold i klassen læste endnu efter »Ole Boles« første bog. Samtidig med, at børnene larte at læse ordene, lærte de også at skrive dem, og på den måde lærte de efterhånden ABC. Fldste hold havde afskrivning efter deres bog og enkelte små diktater og stile.

Regning. Frk. Holm havde regning med alle tre klasser. De brugte »Landsbyskolens Regnebog« af Fr. Friis-Petersen, J.L.W.Jessen og H.P.H.Novrup. Hver time indledtes med hovedregning. Alle fire regningsarter fik man igennem enten sammen eller enkeltvis. De havde efterhånden fået meget stor færdighed $i$ at arbejde med selv store tal $i$ hovedet. Barnet skulle, når det sagde resultatet, gøre rede for fremgangsmåden. På den måde søgte man at lære børnene virkelig at regne hovedregning og ikke skriftlig regning $i$ hovedet...

Med skriftlig regning arbejdede børnene i hold. Det interesserede dem meget mere at få lov til at regne $i$ bøgerne end at have hovedregning. Så kappedes de om, hvem der nåede længst og fik flest r'er. De fleste børn var dygtige til talhandling. Men for mange kneb det at forstå ting som procentregning og forholdsregning.

I yngste klasse lærte børnene at regne ved hjælp af kuglerammen, pinde og deres egne fingre.

Religion. Skoledagen begyndte med, at alle børnene i fælleskab sang morgensang. Vi sang forst en morgensalme, og lærer Madsen bad fadervor, og vi sluttede med at synge endnu en salme. Det var smukt at høre de kønne lyse børnestemmer synge og se de sunde, brune børn andægtigt og stille folde 
hænderne og lytte til fadervor. Det var en smuk optakt til dagens gerning, og den samme smukke ånd prægede religionstimerne. Lærer Madsen fortalte og forklarede smukt og objektivt de forskellige historier fra gammel og ny testamente og fra kirkehistorien. Mange af vore smukke salmer lærte børnene udenad og fik dem samtidig forklaret, så det ikke blev til tomme ord for dem uden betydning. I vinterhalvåret lærte børnene i ældste klasse deres katekismus, medens de om sommeren havde kirkehistorie.

Historie. Kendskab til vort lands og folks historie fik børnene dels gennem læsning i deres egen bog »Danmarks Historie« af Nik. M. Helms og i »Fortællinger af vort Folks Historie« af Thorvald Nørlyng, bogsæt som skolen fik fra vandrebiblioteket, og dels gennem lærer Madsens fortælling. Lærer Madsen forstod at gøre stoffet levende, så børnene lyttede med spændt opmærksomhed. På turen til Haderslev var vi også på museet, og det var børnene meget optaget af at se, især alt hvad der havde tilknytning til deres egen egn interesserede dem. Verdenshistorie fik børnene kun i hovedtræk gennem lærer Madsens fortælling. Det, der havde tilknytning til Danmarkshistorien, blev mere indgående behandlet.

Geografi. Geografi var børnene lige så optaget af som af historie. De lyttede opmærksomt til, hvad man fortalte, især var de optaget af, hvad man selv havde oplevet og set på ture og rejser. Navnene lærte de ved kortøvelser, og de vigtigste ting om landene efter deres bog "Geografi for Folkeskolen « af Christensen og Krogsgaard. Hovedvægten blev naturligvis lagt på Danmarks geografi, og den fik de et indgående kendskab til.

Naturfag. Inden for de timer, der i skemaet benævnes naturfag, falder naturhistorie og fysik. Af disse to fag bruges langt de fleste timer til naturhistorie. Frk. Holm bruger Axel Nielsens arbejdsbøger. Børnene får et godt kendskab til de dyr og planter, de kender fra naturen. Det er især dyrenes og planternes liv og tilpasning, de lærer om. Børnene har arbejdsbøger, hvori de tegner og skriver om dyr og planter.

Fysik drives nogle få timer om vinteren. Det er fortrinsvis dagliglivets fysik, der læres om. Men da der næsten ingen fysiske apparater findes, er det méget vanskeligt at drive fysikundervisning.

Tegning. Tegning drives som fag i de to sidste klasser; i yngste klasse får børnene lov til at tegne frit. I mellemklassen har frk. Holm tegningen. Det er udelukkende mønstertegning efter Herman Thomsens system. Det interesserer især pigerne, og de laver nydelige ting. I ældste klasse tegnede de i bøger med fortegninger...

Sang. Ud over morgensangen synger børnene ikke uden for sangtimerne, men da synger de til gengæld meget og kønt. Her må man dog undtage første klasse, hvor sangen hører med i undervisningstimerne. Lærer Madsen har sang 
med de to ældste klasser sammen. Timerne bruges fortrinsvis til at lære og til at synge sange og salmer $i$. Men timerne indledes med vejrtræknings- og stemmeplejeøvelser. Også skalaøvelser og nodelæsning lærer børnene lidt af. Børnene er delt $\mathrm{i} \mathrm{A}$ og $\mathrm{B}$-sangere. Efterhånden når nogle af $\mathrm{B}$-sangerne så langt, at de kan synge rent sammen med A-sangerne. Børnene holder meget af at synge. De vil helst synge nyere fædrelands-, ungdoms- og årstidssange. Børnene synger efter sangbogen "Arvesølv«, der har et rigt udvalg af salmer og alle mulige sange.

Undervisningsmateriale. Skolen sørger for alt materiale til børnene undtagen kladdehæfter, blyanter og penne. Af bøger har skolen bogsæt til dansk, resten af lærebøgerne anskaffer børnene selv. Mindrebemidlede børn kan låne bøger af skolen. Skolen er medlem af skolecentralen og vandrebiblioteket og får derfra bogsæt, film og lysbilleder til brug i undervisningen. Af andet undervisningsmateriale findes bibelske billeder og landkort; mange af dem stammer fra tysk tid og bruges ikke meget. Tavlen er et uundværligt inventar $i$ et klasseværelse. Den bruges meget af læreren til tegning og forskrift, men af børnene bruges den ikke. I de to yngste klasser bruges skiffertavle som kladde. Det har den fordel, at børnene let kan få kladden rettet, inden de fører ind $\mathrm{i}$ deres bøger.

Skolens organisation. Bevtoft skole er en kommunal skole. Tilsynet med skolen føres af en skolekommission, der består af 5 medlemmer:

smedemester Gubi (formand)

fru forpagter Helga Holm

gårdejer Nis Nieisen

husmand Chr. Christensen

rentenyder Sørensen.

Kommunen lønner de to lærerkræfter, førstelærer Madsen: grundløn $2700 \mathrm{kr}$. og frk. Holm: grundløn $2220 \mathrm{kr}$.

I marts holder skolen eksamen eller forældredag. Så møder de fleste af børnenes forældre for at høre, hvad børnene kan.

\section{NOTER OG HENVISNINGER}

1. Festskrift til Haderslev Statsseminarium $i$ anledning af 50 års jubilæet. Udg. af Haderslev Seminariesamfund 1970 s. 27 og $40 \mathrm{f}$.

2. Nina Langkilde: "Den strătakte landsbyskole«. SJy Årb 1988 s. 88-90.

3. Chr. Stenz: Dansk lærer i grænselandet. Senderjyske Levnedsløb 23, 1982 s. 43.

4. Sprogforeningens Almanak 1989 s. 126 f. Se også Johs. Finks arkiv i Arkivet ved Dansk Centralbibliotek for Sydslesvig (ADCB) P 302. Her findes Skovhuse rapporten. 
5. Sprogforeningens Almanak 199l s. 133. Se også Anna Schrøders arkiv i ADCB P 270. Her findes Bevtoft-rapporten.

6. Se vedr. Rønhave Gunnar Solvang: Husmandsliv. En etnologisk skildring af livsvilkårene $i$ Rønhave-kolonien på Als 1925-80. Landbohistorisk Selskab 1984. Om skolen s. 76-78. Skovhuserapporten gengives her uforkortet.

7. Bevtoft-rapporten gengives forkortet. Udeladt er enkelte udpraget vurderende, psykologiske betragtninger vedr. børnene og deres hjem, vedlagte eksempler på skoleopgaver (diktat, genfortælling, naturfag og tegninger) samt undervisningsplan og timeplaner. 
